\title{
Discussion on HVAC of Super High - rise Buildings
}

\author{
Yuling Miu \\ Department of Power Engineering, School of Energy, Power and Mechanical Engineering, North \\ China Electric Power University, Baoding, Hebei 071003, PR China
}

535368209@qq.com.

Keywords: High-rise buildings, HAVC, comfort.

\begin{abstract}
With the continuous progress of urbanization, Land resources in urban areas are scarce, and because of China's large population, the high rate of residential demand urgent. Some mainly central cities have appeared in high-rise buildings, and they gradually become the city's logo. Whether it is people's life or work, high-rise buildings have become one of the main gathering place. In such circumstances, HVAC system has become an indispensable part of the super high-rise building. In addition to high-rise buildings Functional specificity, making the HVAC design in accordance with the actual characteristics of the building carry out, so as to ensure the overall comfort within the building.
\end{abstract}

\section{The problems of high-rise building}

\subsection{Poor indoor air environment}

In the field of architecture, a building with a height of more than $100 \mathrm{~m}$ is called a super-high-rise building. As the height of the super-high-rise building is large, the wind speed increases as the height of the building increases, and the living environment become uncomfortable. At the same time, the wind will also cause great noise to the interior, through the high-rise building research indicates, said living in the 15-25 layer of the user most of the sound environment and living uncomfortable troubled.

\subsection{Large fire safety hazards}

High-rise building fire has become the focus of world attention, especially in high-rise residential buildings in the event of fire. When the smoke is not blocked, only about $1 \mathrm{~min}$ can spread to dozens of high-rise buildings. The flow rate of flue gas is much higher than that of the crowd. Staircase, elevator shaft and a variety of vertical tube wells is a high-rise residential building fire vertical spread of the important way, easily to form a "chimney effect." According to the survey, the proportion of fires in the fire accounted for $85 \%-90 \%$ of the total number of fires, while the wind speed in the upper part of the super high-rise building was higher and the fire was likely to intensify. And supertall extinguishing rely mainly on internal fire control facilities in the first place to put out a fire, as soon as the fire spread by, difficulty will increase exponentially after put out rescue.

\subsection{Less public communication space}

High-rise residential buildings accommodate overweigh 200 households, and some even up to six or seven hundred. Thus, when the number of residents reaches 100 or more, basically, there is only few mutual understanding between each other. The interior relatively closed for the high-rise residential living environment. Consequently, neighborhood known risk of lower because of the high density residential patterns .At the same time, since staying away from the ground life, it is essential for dwellers living in high-rise buildings which limit their life space live without elevators.

\section{The solutions to the above problems}

\subsection{Taking reasonable construction measures}

During the construction, the construction technology should be consistent with the actual construction situation, developing a scientific and reasonable construction program, and according to the actual situation of HVAC projects, to carry out targeted adjustments. Construction process design should take into account the possibility of the HVAC construction of the security risks. To solve this 
problem, we must strengthen the safety of construction technology research, so that the construction can be safely and smoothly complete.

\subsection{The air exchange space supply}

Taking into account the number of residential households and the number of public space with the number of units to open up part of the floor space will be high-rise residential divided into a number of groups which set up the activities of space and places of communication. Setting up public communication platform in the high-rise residential internal and in the closed indoor space which introduce of space characteristics with significant differences in the public activities of the atrium to promote the exchange between residents and a sense of belonging. At the same time also can increase the green belts, or set up on the roof of a tall building gardens and other places of entertainment, to meet user communication space at the same time, green also can have certain sound insulation effect, the indoor temperature and humidity have certain regulation effect.

\subsection{Adopting reasonable construction shape}

Reasonable building shape design can be a good reduction in the area of paralysis, thereby reducing the impact of the wind on the building. At the same time, a reasonable plane layout and window mode can effectively adjust the indoor air environment, increase high indoor comfort. In high-rise buildings, however, for 15 of the following, as far as possible take to open a window, make indoor airflow through each other, in order to use natural ventilation to improve indoor comfort. For more than 15 layers, try to avoid the window, so that the air flow in the room after the roundabout, so as to improve the uniformity of indoor air distribution to achieve the use of natural ventilation to improve the indoor environment for the purpose of comfort, but also reduce the noise pollution.

\subsection{Smoke control system}

\subsubsection{Smoke protection system}

Smoke protection system design, in addition to the way can be used natural smoke outside the staircase, smoke staircase, fire elevator combined with the front room and enclosed refuge areas, are set up mechanical pressurized air supply system. Stairwells are provided with self-enclosed louvers. The front chamber is provided with a normally closed tuyere on each floor, which opens the fire and the upper and lower vents, and the system is centrally controlled by the fire center. Share of supply air shaft between the ground and underground stairs using electric normally closed tuyere, the fire choose to open. In addition to the bathroom, all rooms should be set up automatic fire alarm system. Except the kitchen selection of temperature detectors, other rooms should use smoke detectors.

\subsubsection{Exhaust system}

Residential floor of the atrium according to the fire norms use natural smoke way, window area and open the way to meet the requirements of fire regulations. Underground garage set up mechanical exhaust system, according to 6 times / $\mathrm{h}$ design smoke, and according to the standard set of fire when the wind or the use of natural lane natural wind. Stairway and its front room or the combination of the former room is a temporary evacuation and shelter of personnel. Fire elevator and its front room is the firefighters into the high-rise building fire main channel. In order to prevent the flue gas from entering these parts or to discharge these parts of the flue gas, to ensure the safe evacuation and rescue of personnel, regardless of whether the conditions open the window for natural smoke, should be designed mechanical pressurized air supply system, and fixed window.

At the same time, research suggestion that the staircase plus positive pressure, the corridor mechanical exhaust is a reliable way to prevent smoke. The purpose of the pressurized air supply to the staircase is to prevent the positive pressure of the smoke staircase higher than the positive pressure in the fire area to prevent the smoke from entering the smoke staircase. The evacuation route, which is affected by the smoke, is the time for the safe evacuation of the personnel. The wind speed, spacing, type and wind speed of the main air duct of the pressurized air supply system of the smoke staircase have a great influence on the operation effect of the system. Recommended pressure air pressure should not be too high. Because the door of the smoke staircase is opened, the pressure of the positive pressure air supply system increases the air volume, and the wind speed of the positive pressure air supply will increase a lot. 


\section{HVAC aspects of energy conservation}

With the increase in building height, the problem of energy consumption of HVAC systems is becoming more and more serious, can from these following measures to reduce the energy consumption of air conditioning. The use of variable air volume air conditioning system, air conditioning units are used to change the new return air ratio control, the transition season can bring out a new wind operation to achieve energy saving purposes. Improving the air conditioning system for the return water temperature difference, although increasing the temperature difference will reduce the refrigerator cooling efficiency, on the whole it is energy-saving. winter when the outdoor wet bulb temperature as low as a certain temperature $\left(5^{\circ} \mathrm{C}\right)$, open the cooling tower, water pump and plate heat exchanger free cooling, cooling capacity to meet the dynamic area of the building load . The whole air system uses the new air volume for the minimum air flow and the transition season for the new wind, to maximize the use of natural cold source.

\section{The Conclusion}

According to the survey statistics, the satisfaction rate of high-rise building residents was significantly higher than high-rise buildings, and high-rise buildings will become the mainstream of urban construction trends. With the development of high-rise buildings, HVAC industry will certainly put forward greater challenges. Therefore, the high-rise buildings may exist in the study of the need to meet the premise of living safety, both the comfort requirements and building energy efficiency.

\section{References}

[1] Guo Wenrui. Study on Safety Management Method of High - rise Building HVAC Construction Site. Henan Building Materials. Vol. 42 (2016) No. 5, p. 56-57.

[2]Guo Liyan. Analysis of high - rise building HVAC system design principles. City Building. Vol. 42 (2016) No. 27, p147.

[3]Xu Zhihua, Feng Wujun, Zhang Yingbing, Mou Fu. The influence of near-ground wind environment on human settlements in high-rise buildings and the use of landscape architecture design measures. Journal of Beijing Normal University (Natural Science). Vol. 42 (2015) No. 51, p. 127-132.

[4] Wei Yuanyuan. Discussion on the professional design and energy saving operation of HVAC in super high - rise building. The Third Annual Conference on Civil Engineering in Central and Western China. Hubei. May 9, 2013. p. 83-85.

[5] Li Mo. Study on the Residence Pattern of Super - high - rise Residential Buildings. Fujian Architectural Construction. Vol. 42 (2009) No. 6. p. 12-14+28.

[6] Liu Huiyuan. Apartment - style super - high - rise residential HVAC design. Housing Science. 2009 Vol. 42 (2009) No. 7, p. 49-52. 